\title{
Dwarfing-canopy and rootstock cultivars for fruit trees
}

\author{
Luiz Carlos Donadio ${ }^{1}$, Ildo Eliezer Lederman ${ }^{2}$, Sergio Ruffo Roberto ${ }^{3}$, Eduardo Sanches Stucchi ${ }^{4}$
}

Abstract - As fruit trees generally have a large size, the production of small or even dwarf trees is of great interest for most of fruit crops. In this review, some of the main tropical, subtropical and temperate fruit trees that have small or even dwarfing cultivars are approached. The causes of dwarfism, although the use of dwarfing rootstocks, is the main theme of this review. The factors that affect the size of the fruit trees are also approached, as well the dwarf cultivars of banana, papaya and cashew, and the dwarf rootstocks for guava, mango, anonaceae, loquat, citrus, apple and peach trees.

Index terms: high-density plantings; spacings; dwarf fruit trees.

\section{Cultivares-copa e porta-enxertos ananicantes para plantas frutíferas}

Resumo - Como as plantas frutíferas apresentam em geral porte elevado, a obtenção de plantas de porte reduzido, ou até anãs, é de grande interesse na fruticultura. Nesta revisão são comentadas algumas das principais plantas frutíferas de clima tropical, subtropical ou temperado que têm variedades de porte reduzido, ou mesmo anãs. As causas do nanismo e o uso de porta-enxertos ananicantes são os principais temas desta revisão. São abordados também os fatores que afetam o porte das plantas frutíferas, as variedades-copa anãs em bananeira, mamoeiro e cajueiro, bem como os porta-enxertos ananicantes para goiabeira, mangueira, anonáceas, nespereira, citros, macieira e pessegueiro.

Termos para indexação: plantios adensados; espaçamentos; plantas frutíferas anãs.

\footnotetext{
Corresponding author:

sroberto@uel.br

Received: June 08, 2018

Accepted: September 21, 2018

Copyright: All the contents of this journal, except where otherwise noted, is licensed under a Creative Commons Attribution License.
} 


\section{Dwarfism in fruit trees}

For more than four decades, the usefulness of dwarfing canopies and rootstocks has been discussed to control the vigor and size of fruit trees, and for several of them, there was already information about the genetic origin of dwarfism and its application in fruit growing. Thus, for apple trees (Malus domestica), small plants could be obtained by inbreeding, but since the use of rootstocks was necessary, the vigor of the canopy could be altered (JANICK; MOORE, 1975).

Due to its juvenility, the long time required for seedlings evaluation was also a factor that affected the studies until obtaining the fruiting. In an apple tree, other factors should be taken into account, such as cold tolerance, the requirement of chilling units, the season or flowering season, the duration of the juvenile phase, the size, color and shape of the fruit, as well as other factors characteristics such as russeting, pulp color, flavor and resistance to pests and diseases (JANICK; MOORE, 1975).

For rootstocks, obtaining new varieties should also be evaluated until the trees start bearing fruits, which requires a long time. The rootstock should be easy to be propagated by seeds or cuttings, easy to graft, to have a root system that supports the canopy, to induce early and good production, as well to have a high resistance to cold in some areas.

Rootstocks that induce dwarfism in apple trees already existed in the 1970s, but they were not associated with disease resistance and cold tolerance. Some Malus species are apomictic and allow vegetative propagation via seeds, which was an advantage because of their genetic uniformity, but there was the occurrence of incompatibility with the commercial apple tree.

For pear (Pyrus communis), the same requirements could be cited, including the obtaining of dwarf rootstocks, in addition to the main quality, which varies from one region to another, and due to the different species. The use of quince (Cydonia oblonga) for pear tree rootstocks has been done for a long time, which resulted in some canopy reduction, but it was necessary to develop pecan rootstocks for better compatibility, besides being more resistant to diseases and cold. One of the first dwarfing rootstocks, denominated US 309, was obtained in Beltsville, USA. To obtain rootstocks, some types of pear trees could be multiplied by cuttings, but the most common was the use of seeds, which caused greater variation in canopy size and lack of uniformity, which was not desirable. Other species were also used as a seed source to obtain rootstocks, such as Pyrus nivalis, but all resulted in vigorous plants (JANICK; MOORE, 1996).

For grapevines, the need to use American rootstocks tolerant to phylloxera (Vitis riparia, Vitis rupestris and Vitis berlandieri) was the most relevant change in the crop of the $19^{\text {th }}$ century. In addition to being resistant to this pest, the rootstock should be fully resistant to cold, vigorous, and resistant to other diseases and pests, including nematodes. The vigor of the vine is related to the soil type and the climate, and for table grapes, the use of rootstocks that induce less vigor is desirable due to the greater exposure of leaves and fruits, which induces better quality of bunches.

For peach and nectarine (Prunus persica), breeding programs have given rise to many canopy varieties, aiming to meet several characteristics, such as climatic adaptation, fruit quality and resistance to diseases, as well as the extension of the harvest season with early and late cultivars, both for fresh consumption and for processing. The control of tree vigor is also a goal for the need to use intensive cultivation and mechanical harvesting, which has led to lower production costs and easier harvesting. The use of seed was for a long time the main method for obtaining rootstocks for vigor, pest and disease resistance, and nematodes, but the main one was the resistance to Phytophthora. Dwarf or semi-dwarf rootstock cultivars were obtained in the early 1970s in Canada. Clonal rootstocks were also developed aiming at their uniformity (JANICK; MOORE, 1975).

The propagation of large-sized trees such as pecan nuts (Carya illinoensis) on rootstocks obtained from seeds, even if they are open pollinated, results in high vigor and unevenness of the trees, for which clonal propagation is more adequate. Other species were tested as rootstocks or interstocks, such as shellbark hickory (Carya laciniosa) and other species of the genus Carya.

For avocado trees (Persea americana), the main problem related to rootstock is its susceptibility to Phytophthora, and tolerant varieties such as Duke and G6, Mexican types, have been obtained, in addition to Persea subg. Eriodaphne, which is resistant but incompatible with commercial avocados. Resistance to cold and salinity are goals of obtaining other rootstocks. The size reduction of canopy is adopted by using dwarfing rootstocks such as Persea vars. schiedeana, flocosa and nubigena. Cultivars of the Mexican landrace are smaller in size than those of the Antillean and Guatemalan ones (BERGH, 1976; BROKAW, 1987).

The commercial citrus trees belong to several species of the genus Citrus, in addition to the genera Poncirus and Fortunella, which results in more than 150 recognized species. Also, the hybrids between species of the same genus and between the genera mentioned, result in many combinations and diversity of vigor, quality, resistance to pests and diseases and other characteristics. Citranges, citrumelos and other hybrids were the oldest citrus tested as rootstocks, expanding their use to meet different soil types, resistance to diseases and other important factors. Poncirus trifoliata, also known as 'Trifoliata', and its hybrids have been used as a source 
of resistance or induction of low vigor in many orange cultivars (RECUPERO, 1990).

However, rootstocks should be longevous, induce high yields and good quality of frui tree, and be adapted to the diverse soil and climate conditions. A variant type of 'Trifoliata', known as 'Flying Dragon' (Poncirus trifoliata var. monstrosa) has been tested and used as rootstock or interstock as inducer of dwarfism to the canopy of orange trees, mandarins, grapefruits and other citrus types, but incompatibility has been reported with several citrus cultivars (ROOSE, 1986).

In addition to the traditional examples cited, more recently, several fruit species have been evaluated or named as low-sized trees, which could be used in some cases to reduce the size of the trees, as a canopy or rootstock. Some examples are: hybrid jabuticaba (Myrciaria cauliflora), pitanga (Eugenia uniflora), dwarf cajá (Spondias dulcis), cerrado pear (Eugenia klostzchiana) and dwarf cashew (Anacardium occidentale L. var. nanum).

\section{The effect of rootstocks on fruit trees}

\section{development}

The size of an adult fruit tree - height and canopy spread - is influenced by several factors and features. The local climate, soil type and fruit species (mango, avocado, citrus, cashew etc.) all play an important role. Among the species some varieties/cultivars naturally tend to grow more vigorously than the other. However, the most important determinant of the final size of a fruit tree is the rootstock.

Rootstock not only influences the size of the tree but also provides other characteristics such as earliness in production, some attributes of disease resistance and resistance to extreme temperatures. Thus, regardless of the species / variety used as rootstock, obtained plant will reach, at the adult phase, an ever smaller size than the same plant if it were obtained by seeds (seedling) i.e, through sexual process.

A certain rootstock can be used for a single species or cultivar since different rootstocks confer different properties, such as vigor, fruit size and precocity while others may be selected by their characteristics such as drought resistance, pest roots and diseases. Another desirable feature in a rootstock is its adaptability to environmental conditions among them; tolerance to wet or dry soils, acidity/alkalinity of the soil or high/low air temperature.

In order to give more efficiency to the management and cultivation in the orchard and, particularly, to facilitate harvesting operation is that the system of planting at high densities is currently being used in many different fruit species, particularly deciduous fruit trees. This system, with its advantages and disadvantages, lead, ultimately, to higher yields and consequently higher profits for the fruit grower.

However, this increasing trend in the use of high density in fruit tree crops lead, necessarily, to the need for increased investment in education and researches in order to develop dwarfing rootstocks for intensive crops in tropical and subtropical fruit species as well (STUCHI, 2005).

\section{Dwarfing-canopy cultivars}

While not dealing properly as rootstocks, it is noteworthy, however, some examples of the variety/ cultivar of tropical fruit of great commercial expression that has in the dwarf size of the plants its main phenotypic characteristic.

3.1. Dwarf coconut -The Cocos genus is composed by just the species Cocos nucifera L., but main botanical varieties are distinguished: giant (typica Nar.) and dwarf (nana Griff.). The giant is characterized by producing coconuts with fitness for copra (solid albumen) and it starts the production after 6.5 years after planting, with around 70 fruits.tree . $^{-1}$ year $^{-1}$. The nana Griff., known as dwarf coconut tree, is predominantly of self-pollination, where the stages of formation of male and female flowers occurs at the same. It has narrow stipe with mean circumference of $56 \mathrm{~cm}$ and reaches an average height of $10.7 \mathrm{~m}$. The leaves are short with a length of around $4 \mathrm{~m}$. They bloom early, three to four years after planting and the fruits are usually small, with 120 fruits per tree.year-1. They are susceptible to pests and diseases, and suffer greatly from drought. This variety has been used in breeding programs and also in the production of green coconut to water supply. The dwarf variety is made up of yellow cultivars, green, red prawns and red of Malaysia. In Brazil, the main demand for planting is the green cultivar.

A third type is the hybrid, commonly called dwarfgiant, resulting from a cross between the varieties dwarf and giant. The hybrid has both characteristics of the dwarf variety and giant, allowing exploration for copra and water as well (SIQUEIRA et al., 2002).

3.2. Banana - In the banana crop (Musa spp.), several cultivars and clones emerged through mutations. Within the Cavendish group, 'Nanicão' had its origin through the natural mutation of 'Nanica', whereas the 'Nanicão Corupá' is a clone from a natural variation in the field. In the Prata group, 'Prata-Anã' ('Enxerto') appeared in the beginning of the XX century in the south of Santa Catarina state, brazil, from a mutation of 'Branca', and 'Prata-Catarina' is a clone and had its origin in the year 1997 from a natural variation of 'Prata-Anã'. The introduction of 'Prata-Anã' in the north of the State of Minas Gerais, Brazil, occurred in the 1990s, and from there, many somaclonal variants have been selected by the producers (CRESTE et al., 2003). 
Among the generation sources of genetic variability in banana crop, natural mutations and somaclonal variations from the in vitro culture are mentioned. The mutants and somaclonal variants are considered important sources of variability and can be used directly or indirectly in breeding programs to develop new cultivars, or even in the selection of superior clones of banana (LICHTEMBERG; MOREIRA, 2006).

3.3. Papaya - The 'Waimanalo' papaya (Carica papaya $\mathrm{L}$.), developed in Hawaii, is the result of crossing a Solo type variety of papaya and ' $\mathrm{X}-77$ '. The plant produces its first flowers at a mean height of $80 \mathrm{~cm}$ and the round shape fruit with a short stalk, weighing from 0.5 to $1.2 \mathrm{~kg}$. The skin is smooth and glowing with a starry cavity, thick pulp, firm, orange-colored flesh, sweet taste and good post-harvest storage capacity. The plant grows fast and comes to bear fruit within 9 months (DAS; DINESH, 2013).

Another dwarf papaya, 'Lal Pari F1', is a hybrid developed in India. The fruit reaches the weight between 1.5 to $2.0 \mathrm{~kg}$ with a red and bright pulp and high content of soluble solids. The plants reach a maximum height of $1.5 \mathrm{~m}$, start producing within 8-9 months after planting, and produce on average 50-60 fruit per plant. This hybrid does not have male flowers and has shown to be tolerant to Papaya Ringspot Virus (PRSV).

In Brazil, a papaya known as 'Baixinho de Santa Amelia', which stands out for small plant size, has been used in an attempt to enable the protected papaya cultivation. It is a natural mutant from Solo Group, although carries some marketing problems mainly linked to the consistency of the pulp and fruit size. First flowers appear 50 to $70 \mathrm{~cm}$ from the ground, and the production start in the 8-9 months after planting, with yield standing around 50 t.ha $^{-1}$.year ${ }^{-1}$.

3.4. Cashew - The early cashew (Anacardium occidentale L. var. nanum) is also known as 'dwarf cashew', 'cashew dwarf precocious', 'cashew-of-Ceará', and 'cashew-of-Ceará-of-six months'. The main early cashews are the clones CCP06 (yellow peduncle), CC09 (yellow), CCP76 (red), CCP1001 (red), Embrapa 50 (yellow), Embrapa 51 (red), BRS 189 (red), BRS 226 (orange), BRS 253 (red) e BRS 265 (red). For comparison purposes, below are presented the main characteristics of the two types of cashew, common and early or dwarf:

3.4.1. Common cashew: tall plants (6 to $12 \mathrm{~m}$ height), exceptionally 15 to $20 \mathrm{~m}$ in fertile soils, wingspan 10 to $20 \mathrm{~m}$, erect canopy, sprawling to compact. Flowering occurs when plants are around 3-5 years old, the weight of the nut is 3 to $33 \mathrm{~g}$, peduncle weight of 20 to $500 \mathrm{~g}$, with yellow or red color. It produces on average 100-200 $\mathrm{kg}$ of nuts per season, and stabilizes the production in the $8^{\text {th }}$ year. The flowering lasts 4 to 5 months and plant lives around 35 years (CRISÓSTOMO et al., 2001).

3.4.2. Dwarf cashew: short sized plant ( 2 to $4 \mathrm{~m}$ of height), compact canopy (around $7 \mathrm{~m}$ wide), upright, propagated by grafting, layering or cuttings. Dwarf cashew starts blomming after 6 months, one month before the common cashew, and flowering lasts 7 to 9 months. The fruit and the peduncle weight from 3 to $13 \mathrm{~g}$, and 40 to 198 $\mathrm{g}$, respectively. It produces on average 1,200 kg.ha ${ }^{-1} \cdot \mathrm{year}^{-1}$ under rainfed conditions (nonirrigated), reaching up 5,200 $\mathrm{kg} \cdot \mathrm{ha}^{-1}$.year ${ }^{-1}$ under irrigation conditions (CRISÓSTOMO et al., 2001; ADIGA et al., 2014).

\section{Dwarf rootstocks for tropical and subtropical fruit species}

Although most of the dwarf rootstocks in use and widely diffused among growers have been developed for the main temperate fruit trees, the following are some successful experiences of their use for some tropical fruit trees:

4.1. Guava -A promising guava (Psidium guajava) aneuploid rootstock with dwarf characteristics for planting in high density orchards was developed at the IARI Fruit and Vegetable Technologies Division, India. It is a tetrasomic rootstock developed by the crossing of the diploid guava 'Allahabad Safeda' with a triploid without seeds. The new rootstock was evaluated by having the 'Allahabad Safeda' as canopy, planted at a spacing of 3 $\times 3 \mathrm{~m}\left(1,111\right.$ trees.ha $\left.^{-1}\right)$, and reaches a yield of 28 tons. $\mathrm{ha}^{-1}$. The trees reach 3 to $4 \mathrm{~m}$ in height, produce fruits of medium to large size, attractive green color and are sweeter than those obtained in orchards using seedlings of the guava 'Allahabad Safeda'. In addition to the dwarf characteristics, this rootstock also showed tolerance to the decline of guava, the main disease that affects the crop under field conditions (POMMER; MURAKAMI, 2008).

4.2. Sapoti - Although sapoti seedlings (Manilkara zapota) have been used as rootstock for the production of grafted nursery trees, other species are also suitable, such as $M$. emarginata and $M$. hexandra, which have been recommended as possible dwarf rootstocks for the crop. Other species, such as Bassia latifolia, B. longfolia, Sideroxylon dulcificum and Mimusops hexandra have also been used successfully. In India, the species M. kauki and M. latifolia are also used as rootstocks, while in Sri Lanka the species $B$. longfolia, also known as Mee, is commonly used as a rootstock for sapoti trees (LEDERMAN et al., 2001).

4.3. Mango - Recently, one of the main objectives of the research on mango production (Mangifera indica) is to obtain short plants by using rootstocks with dwarf effect, such as Indian mangoes 'Mallika' and 'Amrapali'. The latter, a monoembryonic type, independently of the canopy cultivar, reduces the size of the mango tree (PINTO 
et al., 2011).

In India, double-grafting has been observed as an efficient method to obtain dwarf trees in mango and to induce early production. Some hybrid trees such as 'Julie' were naturally produced. The Indian polyembryonic mangoes, 'Olour' and 'Vellai Colamban', when used as rootstocks have dwarf effect, as well as 'Sabre', also a polyembryonic cultivar, in trials carried out in Israel and South Africa. In Peru, 'Manzo de Ica' is used as rootstock, as well as 'Hilaza' and 'Puerco' in Colombia, and 'Kaew' and in Thailand (REDDY et al., 2003).

In Brazil, hybridizations have been carried out in order to obtain a dwarf, prolific, disease-resistant and high-quality fruit of mango (PINTO et al., 2011). Among the first-generation (F1) of mango hybrids and progenies obtained from backcrossing, the selection CPAC 07.294/94 presents dwarf size and early production at two years of age, but the fruits are of low quality for flavor.

4.4. Annonaceae - In Sri Lanka, when graviola (Annona muricata) is grafted on biribá (Rollinia mucosa) the vigour of trees is reduced. However, the biribá species $R$. deliciosa, when grafted on A. montana or A. glabra rootstocks, has a dwarf effect on the tree.

In Brazil, the 'Anona-do-brejo' (A. glabra) is considered a dwarf rootstock, resulting in small trees, and is indicated for wetlands because it tolerates root rot. When it is used as rootstock for graviola trees, besides conferring a low size to the canopy, it shows good compatibility and facilitates the handling of the crop. The 'Araticum-mirim' (R. emarginata) induces dwarfism of the canopy and has a satisfactory tolerance to root rot, good tolerance to stem borer and good compatibility of grafting for atemoya ( $A$. cherimola Mill $\times$ A. squamosa L.) and cherimoya $(A$. cherimola Mill) (SCALOPI JUNIOR, 2013).

4.5. Spondias - In the Northeastern region of Brazil, studies have been carried out to reduce the size of the cajá trees (Spondias mombin var. lutea), using other smaller species of the Spondias genus, such as umbu ( $S$. tuberosa), seriguela ( $S$. purpurea), and cajá-manga trees (S. dulcis) (SOUSA; BLEICHER, 2002). Although there was no problem of incompatibility among species, there is no conclusive definition of the reduction of plant size. In the case of umbu-cajá ( $S$. tuberosa $\times S$. mobin) grafted on umbu rootstock, the trees started bearing fruits from the second year after being transplanted to the definitive location. Like umbu-cajá, the cajá-manga when grafted on umbu tree as rootstock, started bearing fruits in the second year after the nursery trees planting.

4.6. Loquat - The loquat tree (Eriobotrya japonica) is a subtropical fruit species usually propagated by grafting in seedlings of the same species, which usually results in tall trees. The size of the fruit and earliness of production are two important characteristics in the commercialization of loquat. However, labor costs are high and can reach $75 \%$ of the total cost of production, mainly for fruit thinning and harvest operations. In this way, production techniques were developed in Spain to reduce costs and to increase competitiveness, such as planting in high densities of semi-dwarf trees under protected cultivation.

For this purpose, the 'Quince C' quince rootstock (Cydonia oblonga Mill.), obtained by the East Malling Research Station, England, which was developed for the production of small pear trees (Pyrus communis L.) in high density plantings (CAMPBELL, 2003). The size of 'Magdal' loquat grafted on quince 'Quince C' in Spain, planted at $2.5 \times 1.7 \mathrm{~m}$ spacing (2,353 trees.ha $\left.{ }^{-1}\right)$, has been significantly reduced, reaching a maximum of $1.87 \mathrm{~m}$ in height, which reduces labor costs, especially in the blossom and fruit thinning, as well as in the harvest. In addition, earliness of production and higher yield has been obtained with the use of this rootstock under protected cultivation (HUESO et al., 2007).

4.7. Citrus - The size of citrus trees (Citrus spp.) is specified by the canopy/rootstock combination, soil and phytosanitary conditions. They can be classified according to their height or their canopy size, as dwarf, when it presents less than $40 \%$ of the standard size; semi-dwarf, with $40-60 \%$ of standard size (grafted on 'Rough' lemon); semi-standard, with $60-80 \%$ of the standard size; and standard, with $80-100 \%$ of the standard size (CASTELO; PHILLIPS, 1977). They are also classified according the size or height of the tree, compared to a standard tree with more than $6.0 \mathrm{~m}$ in height: sub-standard $(4.8 \mathrm{~m}$ - reduction of $25 \%$ compared with standard tree); semi-dwarf (3.6 $\mathrm{m}$ - reduction of $50 \%)$; and dwarf $(2.4 \mathrm{~m}$ - reduction of $75 \%$, with no need of latter for harvesting). In this cases, the standard trees are the sweet oranges (Citrus sinensis), the 'Rough' lemon (Citrus jambhiri) and the 'Troyer' citrange (BITTERS et al., 1979).

The citrus canopy cultivars, because of their genetic characteristics, have their own behavior independent of the climate effect, but they are subjected to the influence of the rootstock in which they are grafted (PASSOS and BOSWELL, 1979; ROBERTO et al., 1992). Among all varieties, only the mandarin satsuma 'Clausellina' develops reduced canopy (TRÉNOR, 1987). Grapefruit and lemon trees reach great development, while orange and mandarin trees can be classified as intermediate size (ZARAGOZA et al., 1989).

There are several possibilities to control the size of citrus trees, among them, the use of small cultivars due to their own genetic characteristics, and the use of dwarfing or semi-dwarfing rootstocks, as well as interstocks of related genera, or Citrus itself (GOLOMB, 1988).

4.7.1. The use of small size-canopy cultivars 
The development of small size-canopy cultivars due to genetic improvement is limited due to the large number of cultivars used, since dwarf forms would be necessary for each one. Gene transfer through conventional methods of genetic improvement is difficult, given the high degree of citrus heterozygosis (ROOSE, 1986).

Certain cultivars or species are naturally more vigorous than others. The high vigor of lemon trees (Citrus limon) causes problems for the cultivation of this species (CASTLE; PHILLIPS, 1977). However, some cultivars have genetic characteristics that make them interesting to obtain the control of tree size.

Some cultivars of satsuma mandarin (Citrus unshiu Tan.) and kumquat (Fortunella spp.) have an erect growth habit, but with narrow trees, while others, such as pommelo (Citrus grandis) and 'Skagg's Bonanza' and 'Tulegold' navel oranges (Citrus sinensis) present more compact trees (GOLOMB, 1988). The mandarin satsuma 'Clausellina' has low vigor, but is very productive, being recommended for high-density plantings, spaced at 6.0 $\times 2.0 \mathrm{~m}$ apart (TRÉNOR, 1987). The 'Miyagawa Wase' mandarin is also considered a semi-dwarf cultivar of the satsuma mandarin group (HIRANO et al., 1981).

4.7.2. The use of dwarfing-rootstocks- The rootstocks have the greatest influence in controlling the size of citrus trees. Thus, the control of tree size with the use of rootstocks is of interest, as it would not increase the costs of establishment and management of orchards (ROOSE, 1990; DONADIO; STUCHI, 2011). For this reason, the best solution for a natural size control is the selection of canopies, rootstocks or combinations of them with dwarfing semi-dwarfing characteristics, and the management of the orchards would be done without or with a minimum of requirement of pruning (PHILLIPS, 1969, 1978a).

A dwarfing rootstock is one that, in combination with other parts of the tree and regardless of the influence of pathogens, environment or others, results in an adult tree with a height of not more than $2.5 \mathrm{~m}$ (CASTLE, 1978).

The Poncirus trifoliata rootstock, also known as 'Trifoliate', and some of its hybrids were considered as possible dwarfing roostocks, since the canopies grafted on them show relatively small size. However, many of these effects may be due to the presence of exocortis viroid complex or poor adaptation to certain soil conditions, especially sandy soils where $P$. trifoliata behaves as a substandard rootstock (COHEN 1968; PHILLIPS, 1978a).

'Trifoliate' is compatible with a large number of citrus canopy cultivars, but is incompatible with 'Pêra' sweet orange (Citrus sinensis L. Osbeck.) and tangor 'Murcott' [Citrus reticulata Blanco $\times$ C. sinensis L. Osb.].

There are many selections of $P$. trifoliata, which can be split into two large groups: small flowers (3.0-4.0 $\mathrm{cm}$ ) and large flowers $(5.5-6.5 \mathrm{~cm})$. In the first group they have a bush habit of growing and very branched, and those of the second group present erect growth, without branching, and more vigorous after being sown (BITTERS et al., 1973).

Selections from the small flower group generally produce smaller trees, with higher yield per volume of canopy than those propagated from large flower selections (PHILLIPS, 1978b). Therefore, selections of small flowers, mainly 'Rubidoux', turned prevalent in orchards planted on P. trifoliata from 1950 in California, United States of America (BITTERS et al., 1973).

From the group of large flowers represented by the 'Pomeroy' selection, usually results in trees 15 to $20 \%$ larger than those from the small flower group, which, in turn, induce trees $15-20 \%$ smaller than the standards. The 'Rubidoux' reduces the size of 'Valencia' orange trees $(C$. sinensis) by $42 \% ; 46 \%$ of navel oranges $(C$. sinensis) and $72 \%$ of grapefruit $(C$. paradisi) not affected by known pathogens (BITTERS et al., 1979).

The 'English Small', 'Christiansen' and 'Rubidoux' trifoliate selections form semi-dwarf trees. The 'English Small' selection results in smaller and more productive trees in relation to the canopy size of 'Valencia' sweet orange (PHILLIPS and CASTLE, 1977). The behavior of two trees of zygotic origin of $P$. trifoliata with dwarfing characteristics was verified, indicating the possibility of transferring the dwarfing characteristics of this species by genetic hybridization (RECUPERO, 1990).

The rootstock $P$. trifoliata var. monstrosa 'Flying Dragon' is the only true dwarf rootstock currently known, with a size reduction of $33 \%$. It originated by mutation of P. trifoliata and it is characterized by having the curved spines down and zigzag branches growth. It is tolerant to Tristeza virus, Phytophthora and nematoids, but is susceptible to exocortis and drought. It presents little adaptation to all types of soil, with poor development in alkaline and sandy soils, and induces tolerance to cold. It is a promising rootstock for the control of the size of tangelo 'Minneola' (CASTLE, 1992), and only presents serious problems of incompatibility with 'Eureka' lemon (Citrus lemon) (STUCHI et al., 2003).

High-density plantings of sweet orange grafted on 'Flying Dragon' trifoliate are characterized by high yield. This is due to the greater number of trees in the same area, and these trees present high production efficiency. Another aspect is related to the small size of the adult trees (around $3 \mathrm{~m}$ ), which requires periodic pruning, which is necessary in other types of high-density plantings. The smaller size facilitates harvesting, and inspection and eradication of HLB, thus increasing the efficiency of crop and land spraying, which meets the wishes of most citrus growers regarding pest control, disease and its vectors (STUCHI et al., 2012). 
The 'Flying Dragon' trifoliate induces high productive efficiency for 'Tahiti' lime (Citrus latifolia Tanaka), 'Okitsu' satsuma mandarin (C. unshiu), 'Folha Murcha' sweet orange (C. sinensis L. Osbeck ), 'Ponkan' mandarin (Citrus reticulata Blanco) and other sweet orange cultivars (C. sinensis) (STUCHI et al., 2003; STUCHI and SILVA, 2005; CANTUARIAS-AVILÉS et al., 2010, 2011, 2012; STUCHI et al., 2012; SILVA et al., 2013). It is also worth mentioning the importance of this rootstock for 'Galegão' lime or 'Malay' lemon due to the lower vegetative growth with good fruit production, and recommended for orchards that adopt high-density plantings (STUCHI et al., 2016).

Some hybrid rootstocks and from similar genera also have dwarfing effect on citrus trees. The 'Cunningham' citrange reduces most of canopy cultivars by more than $50 \%$, but trees decline after ten years (BITTERS et al., 1979). The 'C-35' citrange, at eleven years-old, results in small plants with good production of sweet oranges 'Valencia' and 'Washington Navel' (C. sinensis), tangelo 'Minneola' and 'Lisbon' lemon (Citrus limon) (ROOSE et al., 1989).

The 'Thomas' citrangequat is apparently dwarf and very tolerant to cold (PHILLIPS, 1969). 'Valencia' orange trees grafted on Fortunella hindsii hybrid showed good behavior, reaching sizes between 40 and $50 \%$ of the standard (CASTLE; PHILLIPS, 1977).

Dwarfism in 'Valencia' orange trees (C. sinensis) grafted on citrandarin 'Cleopatra' $\times$ 'Christian (712)' is also known, and the trees reach a mean height of $1.9 \mathrm{~m}$ at 16 years-old (POMPEU JR; BLUMER, 2009).

In Colombia, 'Valencia' sweet orange (C. sinensis) grafted on several hybrid rootstocks ('Sunki' tangerine) $\times$ ('Rangpur' lime $\times$ 'Trifoliate'), ('Swingle' citrumelo 033), ('Sunki' tangerine) $\times$ ('Swingle' citrumelo - 041), ('Rangpur' lime) $\times$ ('Trifoliate' - 001), (Trifoliate Hybrid - 051), (Trifoliate Hybrid - 053) and (Trifoliate Hybrid - 069), due the reduction of its size, it was possible to establish high-density plantins when compared to the use of traditional rootstocks, such as 'Rangpur' lime (Citrus limonia Osbeck) and 'Sunki' mandarin [C. sunki (Hayata) hort. ex Tanaka] (RAMOS et al., 2015).

The 'Navelina' navel orange (C. sinensis) grafted onto dwarf rootstocks 'Forner-Alcaide 517' ('King' mandarin $\times P$. trifoliata) and 'Forner-Alcaide 418' ('Troyer' citrange $\times$ Citrus reticulata) resulted in small trees. The results obtained in this study were similar to those of the 'Carrizo' citrange, with good fruit quality and suitable for planting at high densities (FORNER-GINER et al., 2014).

The species Citrus vebberi, Citrus hystrix and Severinia buxifolia result in semi-dwarf trees when used as rootstocks for 'Valencia' orange $(C$. sinensis). The tree height of each combination was $3.6 ; 2.6$ and $3.3 \mathrm{~m}$; the canopy volume was $49.9 ; 25.9$ and $25.9 \mathrm{~m}^{3}$, and the cumulative yield of a period of eight years was 21.5; 22.7 and $15.0 \mathrm{~kg} \cdot \mathrm{m}^{-3}$, respectively (VALLE VALDÉS, 1984).

The use of interstock or filter was proposed as an alternative with the potential to produce dwarfism in citrus trees, with the additional advantage of the possibility of using a rootstock with the most appropriate characteristics to the soil conditions and, or, occurrence of disease, as it has been used in apple trees.

The interstock can influence both the rootstock and the canopy, and can be influenced by both. Some cultivars or species have shown dwarfing effect when used as interstock, which do not present as rootstocks. Among them, the species of related genera Citropsis giletiana and Clymenia polyandra are considered the most promising (PHILLIPS, 1978a).

In a study about the use of related genera as rootstocks and interstocks for 'Eureka' and 'Lisbon' lemons (C. limon) and 'Valencia' or 'Washington Navel' oranges $(C$. sinensis), the results widely ranged in terms of yield and size of the trees, between $25 \%$ and $75 \%$ of the standard size, and the genera Clymenia, Microcitrus, Eremocitrus and Citropsis were considered potential for this purpose (BITTERS et al., 1977).

The 'Star Ruby' grapefruit (Citrus paradisi) with 'Flying Dragon' as interstock, grafted on sour orange (Citrus auratium), 'Swigle' citrumelo, 'Volkamerian' lemon (Citrus volkameriana) and 'Rangpur' lime (C. limonia) resulted in canopy volumes of $65.9 ; 65.3 ; 59.3$ and $52.6 \%$, respectively, when compared to trees without interstock (ASHKENAZI et al., 1992).

The 'Flying Dragon' trifoliate rootstock used as interstock causes considerable reduction of 'Valencia' sweet orange $(C$. sinensis) with both the 'Troyer' citrange and $P$. trifoliata as rootstocks. The average reduction is $37 \%$ compared to trees without interstock. However, 'Flying Dragon' as a rootstock results in an average reduction of $66 \%$ of the canopy size in relation to 'Troyer' citrange and P. trifoliata (ROOSE, 1990).

The 'Flying Dragon' trifoliate as an interstock for 'Tahiti' lime (C. latifolia Tanaka) in combination with 'Volkamerian Catania-2' lime rootstock, 'Orlando' tangelo, 'Morton' citrange, 'Swingle' citrumelo and 'Davis A' trifoliate, was found to have no effect on the height of the trees and on the canopy volume. The interstock effect was dependent on the rootstock, in which the interstock 'Davis A' trifoliate trees were more vigorous than those without insterstock. However, the trees grafted on 'Volkamerian Catania-2' and those with interstock were less vigorous than those without interstock (ESPINOZANUÑEZ et al., 2011). 


\section{Dwarf-rootstocks for temperate fruit species}

5.1 Apple trees - A few decades ago, most apple trees (Malus domestica Borkh.) were propagated by grafting of the cultivar on rootstocks propagated by seeds. However, the use of these seedlings as rootstocks resulted in very large plants that took a long time to produce fruits.

Currently, there are a large number of rootstock options obtained in breeding programs that give the apple variety different sizes, from very vigorous to dwarf. These options present different characteristics, such as resistance to certain pests and diseases, and performance for different edaphoclimatic conditions. Many of these rootstocks also confer earlier production to the apple variety.

Due to their small vigor, apple trees grafted on dwarf rootstocks are easy to prune and harvest, and are therefore used in high-density plantings. However, they require permanent training support because their roots are fragile. The main advantages of orchard densification are the early production, the high productivity, the high quality of the fruits and the lower labor cost.

Currently, the density used in modern plantations varies from 1,000 to 6,000 trees.ha- ${ }^{-1}$, with use of up to 10,000 trees.ha $^{-1}$ in some systems. However, recent studies have shown that the best economic return is obtained with planting densities between 2,000 and 3,200 plants $^{-1}$ (JAMES; MIDDLETON, 2011, ROBINSON et al., 2013, PEREIRA; PASA, 2016).

The success of high-density orchards depends on the use of management techniques to control plant size, such as the correct choice of rootstock (PASA; EINHORN, 2014). Among the several options of dwarf rootstocks in Brazil, stand out the 'M-9' and the 'M-26'. In cases where it is desired to use the 'Maruba' rootstock, which is resistant to root rot, but it is very vigorous, the 'M-9' has been used as a filter or interstock (BERNARDI et al., 2004).

The 'M-9' rootstock, also known as 'Malling 9', is a good choice for varieties of vigorous apple trees. It is recommended for densities exceeding 2,500 plants. $\mathrm{ha}^{-1}$ and requires training system. It results in very early fruiting and high quality fruits. However, it may show problems of sprouting and canopy growth in years of winters or in hot regions. It requires fertile, deep soils with good organic matter content, and water retention capacity.

The 'M-26' rootstock, also known as 'Malling 26', is the result of the cross-breeding between the rootstocks of the EM series (East Malling), whose objective was to obtain rootstocks with dwarf characteristics and, at the same time, with high ground anchoring capacity. It confers early production, usually producing fruit after one year of planting. It produces few suckers and requires training system. It is susceptible to fire blight caused by the bacterium Erwinia amylovora. For 'Royal Gala' and 'Fuji' apple trees, the 'M-26' rootstock results in higher accumulated yield than 'M-9', especially when planted in $4.0 \times 0.5 \mathrm{~m}$ spacing, i.e., 5,000 trees.ha ${ }^{-1}$ (PEREIRA; PASA, 2016).

5.2 Peach trees - The main rootstocks used in the production of peach trees and nectarines (Prunus persica) in Brazil, among them 'Okinawa' and 'Capdebosq', usually confer a high vigor to the trees, which prevents the planting in high density when the forms of vase or opencenter are employed. Thus, recent works involving the use of the japanese apricot (Prunus mume Sieb. et Zucc.) As a peach tree rootstock, this species confers excellent production characteristics and mainly decrease the vigor of the trees, which allows its use in high-density plantations (MAYER et al., 2015).

Also known as chinese plum, the japanese apricot belongs to the Rosaceae family, and it is deciduous tree, originating in mainland China, typical of temperate climate. Its introduction in Brazil was probably by japanese immigrants, with material coming from Taiwan. The use of japanese clones as peach rootstocks has revealed promising prospects for success.

Developed in the 1980's at the Instituto Agronômico de Campinas (IAC), Brazil, the 'Rigitano' clone as a rootstock for 'Aurora-1' peach trees develops satisfactorily, with adequate sprouting, bud formation, fruiting, fruit growth and ripening. The 'Aurora-1' peach grafted on 'Rigitano' produces larger fruits than when grafted on 'Okinawa', with an increase of $10 \mathrm{~g}$ or more, and in equivalent number, which has caused great expectation and optimism to peach growers (PEREIRA et al., 2007).

In California, USA, rootstocks were also developed to control the size of peach trees in order to reduce production costs. In peach and nectarine orchards with small trees, some operations and cultural dealings are facilitated, such as pruning and harvesting. The 'Controller 5 ' and 'Controller 9' dwarf rootstocks are very promising for reducing the height of the peach trees by 50 and $90 \%$, respectively, compared to 'Nemaguard', one of the most widely used rootstocks in California (DEJONG et al., 2005).

In Brazil, the semi-dwarf ' $\mathrm{Nano}^{+}$' rootstock has been recently release, developed by Clone Nurseries. It is a diploid plum, probably hybrid between species, selected in 2004 from a population of open pollination trees for the ability to reduce the vigor of both peach and plum trees. Peach trees grafted on the 'Nano' ${ }^{+}$rootstock have a $40-65 \%$ reduction in canopy size of the variety when compared to the same varieties grafted on rootstocks used currently in Brazil. The trees training can be carried out in as central leader, being possible, due to the small size, the installation of anti-hail screens. It has been verified, through the use of this rootstock, economy in labor in operations such as pruning and peach harvesting, besides dispensing summer prunings under normal conditions. 


\section{Conclusion}

Dwarfing-canopy and rootstocks can be used in several fruit crop production systems, especially in high-density plantings. Some tropical, subtropical and temperate fruit species are available for this purpose, mainly dwarfing-rootstocks, which provides the fruit production under protected and open field cultivation.

\section{References}

ADIGA, J.D.; KALAIVANAN, D.; MEENA, R.K.; MOHANA, G.S. Performance of vigorous cashew cultivars as influenced by dwarf rootstocks. Journal of Plant Research, Tokyo, v.27, n.2, p.242-248, 2014.

ASHKENAZI, S.; ASOR, Z; RASIS, A.; ROSENBERG, O. Flying dragon trifoliate as a dwarfing interstocks for citrus trees. In: INTERNATIONAL CITRUS CONGRESS, 7., 1992, Acireale. Proceedings... Hartley Grove: South Australian R\&D Institute, 1992. Abstract, 201.

BERGH, O.B. Avocado breeding and selection. In: INTERNATIONAL TROPICAL FRUIT SHORT COURSE: THE AVOCADO, 1., 1975, Florida. Proceedings... Flórida: Institute of Food and Agricultural Sciences, University of Florida, 1976. p.83-87.

BERNARDI, J.; DENARDI, F.; HOFFMANN, A. Cultivares e porta-enxertos. In: NACHTIGALL, G.R. (Ed.). Maçã: produção. Bento Gonçalves: Embrapa Uva e Vinho; Brasília: Embrapa Informação Tecnológica, 2004. 171p. (Frutas do Brasil, 37).

BITTERS, W.P.; COLE, C.D. McCARTY, D.A. Evaluation of trifoliate orange selecting as rootstocks for Washington Navel and Valencia orange. Proceedings of International Society of Citriculture, Griffith, p.127-131, 1973.

BITTERS, W.P.; COLE, D.A.; McMARTY, C.D. Facts about dwarf citrus trees. Citrograph, Fresno, v.64, n.3, p.54- 56, 1979.

BITTERS, W.P.; COLE, D.A; McCARTY, C.D. Citrus relatives are not irrelevant as dwarfing stocks or interstocks for citrus. Proceedings of International Society of Citriculture, Griffith, v.2, p.561-567, 1977.

BROKAW, W.H. Field experiences with clonal rootstocks. Yearbook South African Avocado Growers, Tzaneen, v.10, p.34-35, 1987.
CAMPBELl, J. Pear rootstocks. Agfact H4.1.15. Orange: Agricultural Intitute, 2003. 12 p.

CANTUARIAS-AVILÉS, T.; MOURÃO FILHO, F.A.A.; STUCHI, E.S.; SILVA, S.R.; ESPINOZA-NÚÑEZ, E. Tree performance and fruit yield and quality of 'Okitsu' Satsuma mandarin grafted on 12 rootstocks. Scientia Horticulturae, New York, v.123, p.318-322, 2010.

CANTUARIAS-AVILÉS, T.; MOURÃO FILHO, F.A.A.; STUCHI, E.S.; SILVA, S.R.; ESPINOZA-NÚÑEZ, E., BREMER NETO, H. Rootstocks for high fruit yield and quality of 'Tahiti' lime under rain-fed conditions. Scientia Horticulturae, New York, v.142, p.105-111, 2012.

CANTUARIAS-AVILÉS, T.E.; MOURÃO FILHO, F.A.A.; STUCHI, E.S.; SILVA, S.R.; ESPINOZANÚÑEZ, E. Horticultural performance of 'Folha Murcha' sweet orange onto 12 rootstocks. Scientia Horticulturae, New York, v.129, p.259-265, 2011.

CASTLE W.S.; PHILLIPS, R.L. Potentially dwarfing rootstocks for Florida citrus. Proceedings of International Society of Citriculture, Griffith, v.2, p.558-561, 1977.

CASTLE, W.S. Controlling citrus tree size with rootstocks and viruses for higher density plantings. Proceedings of the Florida State Horticultural Society, Gainesville, v.91, p.46-50, 1978.

CASTLE, W.S. Rootstock and interstock effects on the growth of young 'Minneola' tangelo trees. Proceedings of the Florida State Horticultural Society, Gainesville, v.105, p.82-84, 1992.

COHEN, M. Exocortis virus as possible factor in producing dwarf citrus trees. Proceedings of the Florida State Horticultural Society, Gainesville, v.81, p.115-119, 1968.

CRESTE, S.; TULMANN NETO, A.; SILVA, S.OÇ.; FILGUEIRA, A. Genetic characterization of banana cultivars (Musa spp) from Brazil using micro sattelite markers. Euphytica, Wagenigen, v.132, p.259-268, 2003.

CRISÓSTOMO, L.A., SANTOS, F.J.S., OLIVEIRA, V.H., VAN RAIJ, B., BERNARD, A.C. DE C., SILVA, C.A., SOARES, I. Cultivo do cajueiro anão precoce. Aspectos fitotécnicos com ênfase na adubação e na irrigação. Pacajus: Embrapa Agroindústria Tropical, 2001. 20p. (Circular Técnica, 8) 
DAS, S.C.; DINESH, M.B. Evaluation of varieties and hybrids for physic-chemical characters in papaya (Carica papaya L.). The Journal of Horticultural Science, Abingdon, v.8, n.2, p. 234-235, 2013.

DEJONG, T.M.; JOHNSON, R.S.; DOYLE, J.F.; RAMMING, D. Research yields size-controlling rootstocks for peach production. California Agriculture, Sacramento, v.59, p.80-83, 2005.

DONADIO, L.C.; STUCHI, E.S.E. Adensamento de plantio e ananicamento de citros. Jaboticabal: Funep, 2001.70p. (Boletim citrícola, 16).

ESPINOZA-NÚÑEZ, E.; MOURÃO FILHO, F.A.A.; STUCHI, E.S.; CANTUARIAS-AVILES, T.; DIAS, C.T.S. Performance of 'Tahiti' lime on twelve rootstocks under irrigated and non-irrigated conditions. Scientia Horticulturae, New York, v.129, n.2, p.227-231, 2011.

FORNER-GINER, M.A.; RODRIGUEZ-GAMIR, J.; MARTINEZ-ALCANTARA, B; QUIÑONES, A; IGLESIAS, D.J.; PRIMO-MILLO, E.; FORNER, J. Performance of Navel orange trees grafted onto two new dwarfing rootstocks (Forner-Alcaide 517 and FornerAlcaide 418). Scientia Horticulturae, New York, v.179, p.376-387, 2014.

GOLOMB, A. High density planting of intensive citrus groves: a challenge and realization. In: INTERNATIONAL CITRUS CONGRESS, 6., 1998, Tel Aviv. Proceedings... 1998. v.1, p.921-930

HIRANO, S.; MORIOKA, S.; TACHIBANA, S. Tree density age as related to fruit yield area in the Satsuma madarin estimation for an optimum leaf area index on field basis. Proceedings of International Society of Citriculture, Griffith, v.1, p.184-186, 1981.

HUESO, J.J.; CAÑETE, M.L.; CUEVAS, J. High-density loquat orchards: plant selection and management. First Results. Acta Horticulturae, The Hague, v.750, 349354, 2007.

JAMES, P.; MIDDLETON, S. The productivity and economic comparison of high-density production systems for 'Cripps Pink' and 'Cripps Red' apples in South Australia. Acta Horticulturae, The Hague, v.903, p.611-618, 2011.

JANICK, J.; MOORE, I.N. Advances in fruit breeding. West Lafayette: Purdue University Press, 1975. 623p.

JANICK, J.; MOORE, I.N. Fruit breeding. Nuts. (III). New York: Wiley, 1996. 278p.
LEDERMAN, I.E., SILVA JUNIOR, J.F, BEZERRA, J.E.F. E MURA, R.J. M. Sapotizeiro (Manilkara Zapota L., Von Royen). Jaboticabal: SBF, 2001. 71p. (Série Frutas Potenciais).

LICHTEMBERG, L.A., MOREIRA, R.S. - The history and characteristics of the 'Enxerto' banana. In: REUNIÃO INTERNACIONAL ACUBBAT, 17., 2006, Joinville. Anais... Joinville: ACORBAT/ACAFRUTA, 2006. v.2, p.885-887.

MAYER, N.A.; UENO, B.; REIGHARD, G.L. Selection of Prunus mume as rootstocks for peaches on PTSL site. Acta Horticulturae, The Hague, v.1084, p.89-96, 2015.

PASA, M.S.; EINHORN, T.C. Heading cuts and prohexadione-calcium affect the growth and development of 'd'Anjou' pear shoots in a high-density orchard. Scientia Horticulturae, New York, v.168, p.267-271, 2014.

PASSOS, O.P.; BOSWELL, S.B. A review of citrus tree spacing. Citrograph, Los Angeles, v.64, n.9, p.211-218, 1979.

PEREIRA, A.J.; PASA, M.S. Desempenho produtivo de macieiras 'Royal Gala' e 'Fuji'. Pesquisa Agropecuária Brasileira, Brasília, DF, v.51, n.4, p.348-356, 2016.

PEREIRA, F.M.; MAYER, N.A.; CAMPO DALL'ORTO, F.A. Rigitano: nova cultivar de umezeiro para porta-enxerto de pessegueiro. Revista Brasileira de Fruticultura, Brasília, DF, v.29, n.1, p.172-175, 2007.

PHILLIPS, R.L. Citrus tree spacing and size control. Proceedings of International Society of Citriculture, Griffith, v.1, p.319-324, 1978a.

PHILLIPS, R.L. Dwarfing rootstocks for citrus. In: INTERNATIONAL CITRUS SYMPOSIUM, 1., 1969. Proceedings... Riverside: University of California, 1969. v.1, p.401-406.

PHILLIPS, R.L. Hedging and topping citrus in high density plantings. Proceedings of the Florida State Horticultural Society, Gainesville, v.91, p.43-46, 1978 b.

PHILLIPS, R.L.; CASTLE, W.S. Evaluation of twelve rootstocks for dwarfing citrus. Journal of the American Society for Horticultural Sciences, Alexandria, v.102, n.5, p.526-528, 1977.

PINTO, A.C.Q., NETO, F.P. E GUIMARÃES, T.G. Estratégias do melhoramento genético da manga visando atender a dinâmica do mercado. Revista Brasileira de Fruticultura, Jaboticabal, v.33, p.64-72, 2011. Edição Especial 
POMMER, C.V., MURAKAMI, K.R.N. Breeding guava (Psidium guajava L.). In: JAIN, New York: S.M.; PRIYADARSHAN, P.M. (Ed.). Breeding plantation tree crops: tropical species. Springer, 2008. p.83-119.

POMPEU JUNIOR, J.; BLUMER, S. Híbridos de trifoliata como porta-enxertos para a laranjeira 'Valência'. Pesquisa Agropecuária Brasileira, Brasília, v.44, n.7, p.701-705, 2009.

RAMOS, Y; STUCHI. E.S.; GIRARDI, LEÃO, H.C., GESTEIRA, A.; PASSOS, O.S.; SOARES-FILHO, W. S. Dwarfing rootstocks for 'Valencia' sweet orange. Acta Horticulturae, The Hague, v.1065, p.351-354, 2015.

RECUPERO, G.R. Uso de porta-enxertos para plantio de alta densidade. In: SEMINÁRIO INTERNACIONAL DE CITROS - PORTA-ENXERTOS, 1., 1990. Anais... Jaboticabal: FUNEP, 1990. 242p.

REDDY, Y.T.N.; KURIAN, R.M.; RANACHANDER, P.R.; SINGH, G.; KOHLI, R.R. Long-term effects of rootstocks on growth and fruit yield patterns of 'Alphonso' mango (Mangifera indica L.). Scientia Horticulturae, New York, v.97, p. 95-108, 2003.

ROBERTO, S.R.; DONADIO, L.C.; SEMPIONATO, O.; CABRITA, J.R.M.; DE NEGRI, J.D. Tree growth in high densities and costs for citrus planting in Brazil, 7., 1992, Acireale, In: International Society of Citricultura, 7., 1992, Acireale. Proceedings... Acireale: International Society of Citriculture, 1992. p.721-722.

ROBINSON, T.; HOYING, S.; SAZO, M.M.; DEMARREE, A.; DOMINGUEZ, L. A vision for apple orchard systems of the future. New York Fruit Quarterly, Rochester, v.21, p.11-16, 2013.

ROOSE, M.L. Dwarfing rootstocks for citrus. In: CONGRESS OF THE INTERNATIONAL SOCIETY OF CITRUS NURSERYMEN, 2., 1986, Riverside.. Proceedings... p.1-8.

ROOSE, M.L. Porta-enxertos de citros na Califórnia. In: SEMINÁRIO INTERNACIONAL DE CITROS PORTA-ENXERTOS, 1., 1990. Anais... Jaboticabal: FUNEP, 1990. 242p.

ROOSE, M.L.; COLE, D.A.; ATKIN, D.; KUPPER, R.S. Yield and tree size of four citrus cultivars on 21 rootstocks in California. Journal of the American Society for Horticultural Science, Alexandria, v.114, n.4, p.678684, 1989.
SCALLOPI JUNIOR, F.J. Anonáceas: Principais portaenxertos para produção de mudas. Pesquisa e Tecnologia, Campinas, v.10, n.2, jul/dez, 2013.

SILVA, S.R.; STUCHI, E.S.; GIRARDI, E.A.; CANTUARIAS-AVILÉS, T.; BASSAN, M.M. Desempenho da tangerineira 'SPAN Americana' em diferentes porta-enxertos. Revista Brasileira de Fruticultura, Jaboticabal, v.35, n.4, p.1052-1058, 2013.

SIQUEIRA, L.A., ARAGÃO, W.M., TUPINAMBÁ, E.A. A introdução do coqueiro no Brasil, importância histórica e agronômica. Jardins: Embrapa, Tabuleiros Costeiros, 2002. 24 p. (Documentos, 47).

SOUSA, C.A.F.; CAVALCANTI, M.I.L.G; VASCONCELOS, L.F.L.; SOUSA, H.U.; RIBEIRO, V.Q.; SILVA, J.A.L . - 'Tommy Atkins' mango trees subjected to high density planting in subtropical climate in northeastern Brazil. Pesquisa Agropecuária Brasileira, Brasília, DF, v.47, n.1, p.36-43, 2012.

SOUSA, F. X. de; BLEICHER, E. Comportamento da cajazeira enxertada sobre umbuzeiro em Pacajus, CE. Revista Brasileira de Fruticultura, Jaboticabal, v.24, n.3, p.790-792, 2002.

STUCHI, E.S. Adensamento de plantio: Estratégia para a produtividade e lucratividade na citricultura. Revista Ciência e Prática, Lavras, v.16, p.5-6, 2005.

STUCHI, E.S., DONADIO, L.C., SEMPIONATO, O.R. Performance of 'Tahiti lime' on Poncirus trifoliata var. monstrosa Flying Dragon in four densities. Fruits, Paris, v.58, p.1-5, 2003.

STUCHI, E.S.; SILVA, S.R. Plantio adensado da limeira ácida 'Tahiti'. Cruz das Almas: Embrapa Mandioca e Fruticultura Tropical, 2005. 2p. (Citros em Foco, 29).

STUCHI, E.S.; GIRARDI, E.A.; SEMPIONATO, O.R.; REIFF, E.T.; SILVA, S.R.; PAROLIN, L.G. Trifoliata Flying dragon: porta-enxerto para plantios adensados e irrigados de laranjeiras doces de alta produtividade e sustentabilidade. Cruz da Almas: Embrapa Mandioca e Fruticultura, 2012. (Comunicado Técnico, 152).

STUCHI, E.S.; SEMPIONATO, O.R; BREMER NETO, H.; PAROLIN, L.G.; GIRARDI, E.A.; DONADIO, L.C. Limeira ácida 'Galegão': opção às limeiras ácidas 'Galego' e 'Tahiti' na diversificação de pomares. Cruz da Almas: Embrapa Mandioca e Fruticultura, 2016. (Boletim de Pesquisa e Desenvolvimento). 
TRÉNOR, I. Marcos de plantation en citrícos: doblaje e entresaque. Fruticultura Profesional, Barcelona, v.8, p.29-31, 1987.
VALLE VALDES, N. Patrones para cítricos em Jaguey Grande. Ministerio de la Agricultura. Estácion Experimental de Cítricos, Jaguey Grande, Matanzas, Cuba, 1984.

ZARAGOZA, S.;TRENOR, I.;ALONSO, E. Fundamentos de la poda de los agrios. Fruticultura Profesional, Barcelona, v.25, p.51-56, 1989. 